\title{
頸部郭清術前後における鎖骨下静脈の位置と血管径の変化 一中心静脈カテーテル留置の適否について一
}

工 藤 毅 鈴木政美岡田隆 平

要旨 : 頭頸部がんの治療において, 頸部郭清術は欠かせない治療手技の一つである。一方で, 中心静脈カテー テル留置について，鎖骨下静脈からのアプローチは，他の方法より感染のリスクが少ないなどの利点がある。

今回, 頸部郭清術後に鎖骨下静脈からのアプローチが可能かどうかを検討するため, 頸部郭清術前後の CT 画像を用いて, 鎖骨下静脈の位置変化と血管径の変化を測定した。術前後で比較した結果, 位置の変化や血管 径の変化の測定值の変化は少なく, 統計学的な有意差もみられなかった。したがって, 頸部郭清術後において も，鎖骨下静脈からの中心静脈カテーテル留置は可能であると考えられた。

キーワード：鎖骨下静脈，頸部郭清術，中心静脈カテーテル留置

Summary Changes in the position of the subclavian vein and vessel diameter before and after neck dissection:

Takeshi Kudo, Masami Suzuki and Ryuhei Okada. Gunma Cancer Center Hospital, Division of Head and Neck Surgery

Neck dissection is an essential therapeutic technique for the treatment of head and neck cancer, but the subclavian vein approach by a central venous catheter offers advantages such as lower risk of infection than other methods.

To investigate the subclavian vein approach after neck dissection, we used $\mathrm{CT}$ images before and after neck dissection to measure changes in the position of the subclavian vein and vessel diameter.

For 10 patients who underwent neck dissection in our department from March to December 2010, CT images with $2 \mathrm{~mm}$ slices were reconstructed. The results were compared before and after surgery, and the measured changes in the position of the subclavian vein and vessel diameter showed no significant difference. The use of a central venous catheter from the subclavian vein after neck dissection is considered to be possible.

Key words: subclavian vein, neck dissection, central venous catheter

[Received Apr. 3, 2012, Accepted Aug. 22, 2012]

\section{はじめに}

頭頸部がんの治療において, 頸部郭清術は欠かせ ない治療手技の一つである。一方で，中心静脈のカ テーテル留置について, 鎖骨下静脈からのアプロー チは，他の方法よりも感染のリスクが少ないなどの 利点がある。しかし, 頸部郭清術後の鎖骨下静脈の

群馬県立がんセンター頭頸科

[平成 24 年 4 月 3 日受付, 平成 24 年 8 月 22 日受理]
位置変化や血管径の変化についての報告は，われわ れが渉猟した限りでは無かった。

今回, 缅部郭清術前後の CT 画像を用いて, 鎖骨 下静脈の位置や血管径の変化を測定し, 術後に鎖骨 下静脈からの中心静脈アプローチが可能であるかど うかを検討したので報告する。

\section{対象と方法}

対象は, 2010 年 3 月〜 12 月まで群馬県立がん 
表 1 症例

\begin{tabular}{|c|c|c|c|c|c|c|}
\hline & 年齢 & 性別 & 疾患 & 病期 & 郭清範囲* & 術後照射 \\
\hline 症例 1 & 74 & M & 下咽頭癌 & T4aN2bM0 & rt ND（J,pt） & なし \\
\hline 症例 2 & 47 & $\mathrm{~F}$ & 下咽頭癌 & T4bN2cM0 & rt ND（J） & 70Gy \\
\hline 症例 3 & 67 & M & 下咽頭癌 & T4aN2bM0 & rt ND（J,pt） & $32 \mathrm{~Gy}$ \\
\hline 症例 4 & 69 & $\mathrm{~F}$ & 喉頭癌 & T3N2bM0 & lt ND （J,pt） & $50 \mathrm{~Gy}$ \\
\hline 症例 5 & 61 & $\mathrm{~F}$ & 舌癌 & T2N2bM0 & rt ND（SJP） & 50Gy \\
\hline 症例 6 & 64 & M & 舌癌 後発 LN 転移 & $\mathrm{rN} 2 \mathrm{c}$ & lt ND（SJP） & 60Gy \\
\hline 症例 7 & 47 & $\mathrm{~F}$ & 甲状腺癌 後発 LN 転移 & rN1b & rt ND（JP/MV） & なし \\
\hline 症例 8 & 77 & $\mathrm{~F}$ & 上歯肉癌 & T4aN1M0 & rt ND（SJP/MNV） & なし \\
\hline 症例 9 & 52 & M & 中咽頭癌 & T2N2bM0 & rt ND（SJP/MNV） & 60Gy \\
\hline 症例 10 & 63 & $\mathrm{~F}$ & 下咽頭癌 & $\mathrm{T} 2 \mathrm{~N} 2 \mathrm{cM} 0$ & rt ND（JP,pt/MNV） & 60Gy \\
\hline
\end{tabular}

* 郭清範囲の記載方法について

・「/」の前は, 郭清範囲を示す $(\mathrm{S}$ ：オトガイ下・顎下リンパ節， J : 内頸静脈リンパ節， $\mathrm{P}$ : 後頸三角 リンパ節, pt：気管周囲リンパ節)

・「/」の後は, 切除した非リンパ組織を示す（M：胸鎖乳突筋， $\mathrm{N}$ ：副神経， $\mathrm{V}$ : 内頸静脈）

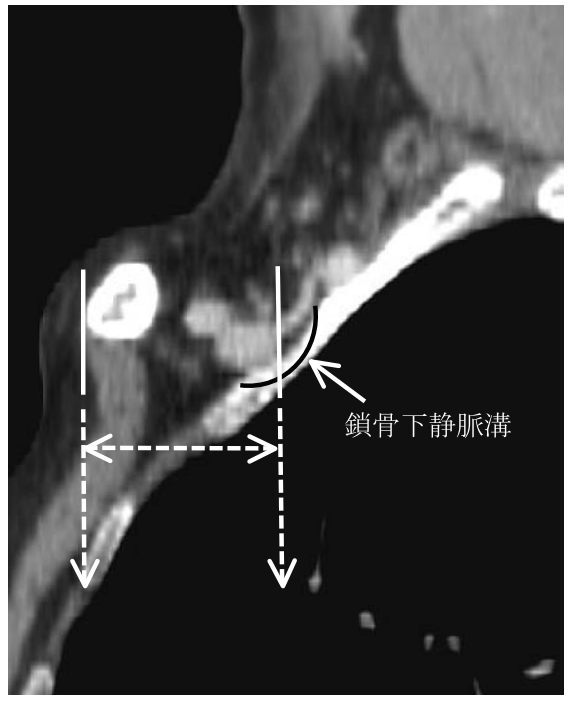

図 1 第一肋骨と鎖骨下静脈の距離の測定方法

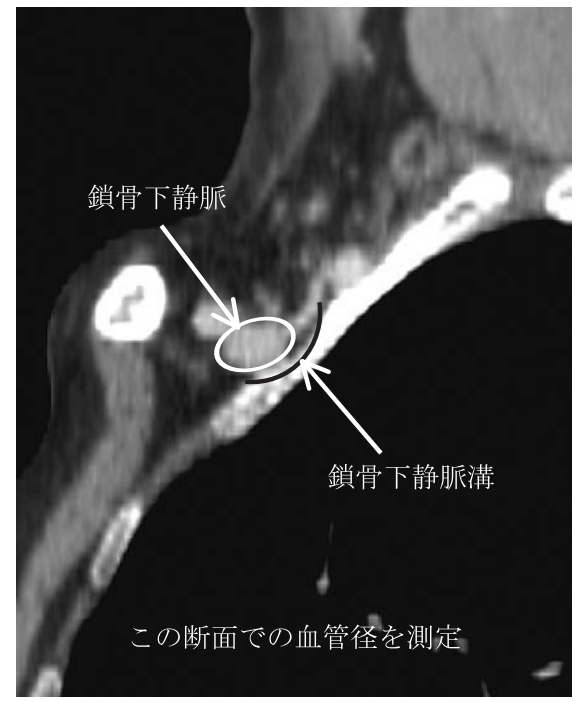

図 2 鎖骨下静脈溝での鎖骨下静脈の血管径の測定
センター頭頸科において頸部郭清術を施行した症例 のうち， $2 \mathrm{~mm}$ スライスで，胸部まで含めた CT 画 像の再構築が可能であった 10 症例（10 側）である （表 1)。性別は男性 4 例, 女性 6 例, 年龄は 47 歳 から 77 歳 (平均 62.1 歳), 術側は右側が 8 例, 左 側が 2 例であった。疾患別では, 下咽頭癌 4 例, 舌 癌 2 例, その他 4 例 (口腔癌, 中咽頭癌, 喉頭癌, 甲状腺癌）であった。また, 郭清領域および術後放 射線治療の有無について, 表 1 に示す。

測定方法については，以下のようにして測定し た。

まずは，鎖骨下静脈溝が描出される矢状断面にお いて，第一胁骨の前端から鎖骨下静脈の後端までの 距離を測定した（図 1)。次に, 同じ断面において, 鎖骨下静脈の長径と短径を測定した（図 2)。また,
その血管径より断面積を求めた。上記の測定結果を 手術前後で比較した。

さらに，鎖骨下静脈溝より $10 \mathrm{~mm}$ および $20 \mathrm{~mm}$ 外側における矢状断面において，図 1 と同様にし て, 第一肋骨の前端から鎖骨下静脈の後端までの距 離を測定し，手術前後で比較した（図 3)。

上記の測定項目について, $\mathrm{t}$ 検定を行い, 統計学 的有意差の有無について検討した。

\section{結果}

鎖骨下静脈溝が描出される矢状断面での鎖骨下静 脈の位置変化は, 最大で $3.5 \mathrm{~mm}$, 最小で $0.2 \mathrm{~mm}$, 平均で $1.48 \mathrm{~mm}$ であった。数值の変化は少なく, 統 計学的な有意差はみとめられなかった（表 2)。血管 径については, 術前の平均值は $13.2 \mathrm{~mm}$ (長径) $\times$ 


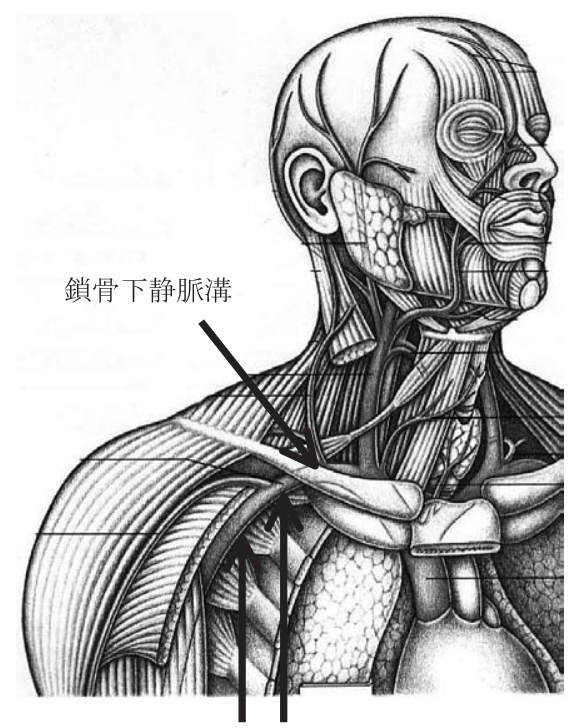

鎖骨下静脈溝より外側 $10 \mathrm{~mm}$ および $20 \mathrm{~mm}$ における血管の位置変化を測定

（文献 1 より引用）

図 3 鎖骨下静脈の解剖学的位置関係

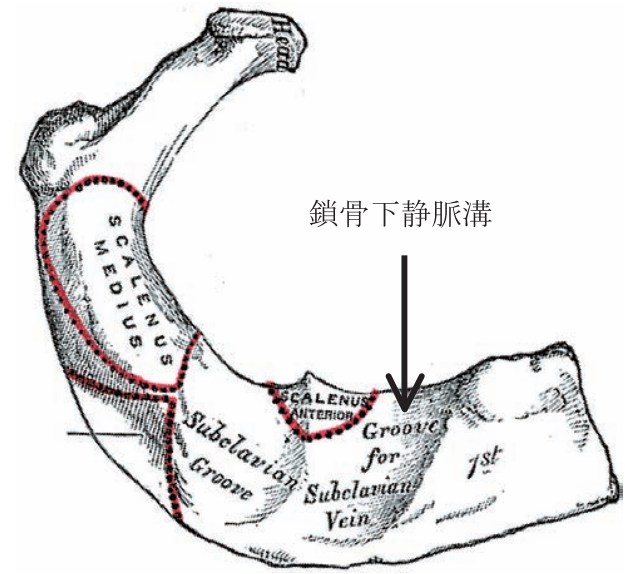

（文献 2 より引用）

図 4 第一肋骨 (鎖骨下静脈溝)

表 2 鎖骨下静脈溝の矢状断面における鎖骨下静脈の位置変化

\begin{tabular}{cccc}
\hline & 術前 $(\mathrm{mm})$ & 術後 $(\mathrm{mm})$ & 変化 $(\mathrm{mm})$ \\
\hline 症例 1 & 31.6 & 32.1 & 0.5 \\
症例 2 & 30.1 & 28.9 & 1.2 \\
症例 3 & 33.5 & 30.4 & 3.1 \\
症例 4 & 26.3 & 25.0 & 1.3 \\
症例 5 & 36.0 & 37.8 & 1.8 \\
症例 6 & 32.8 & 34.2 & 1.4 \\
症例 7 & 30.5 & 31.2 & 0.7 \\
症例 8 & 32.2 & 35.7 & 3.5 \\
症例 9 & 34.1 & 33.9 & 0.2 \\
症例 10 & 28.7 & 27.6 & 1.1 \\
\hline 平均值 & 31.58 & 31.68 & 1.48 \\
\hline
\end{tabular}

$9.3 \mathrm{~mm}$ (短径), 術後の平均值は $12.7 \mathrm{~mm}$ (長径) $\times$ $9.0 \mathrm{~mm}$ (短径) であった（表 3$)$ 。断面積は，術前の 平均值は $96.2 \mathrm{~mm}^{2}$, 術後の平均值は $88.1 \mathrm{~mm}^{2}$ であっ た。血管径, 断面積ともに頸部郭清術前後で統計学 的な有意差はみとめられなかった（表 3）。

鎖骨下静脈溝より外側 $10 \mathrm{~mm}$ における鎖骨下静 脈の位置変化は平均 $1.64 \mathrm{~mm}$, 外側 $20 \mathrm{~mm}$ における 鎖骨下静脈の位置変化は平均 $1.55 \mathrm{~mm}$ であった。こ れらについても数值の変化は少なく, 統計学的な有 意差はみとめなかった（表 4）。

保存的頸部郭清術である症例 $1 \sim 6$ と, 根治的頸 部郭清術あるいは内頸静脈や胸鎖乳突筋を合併切除 した症例 7 〜 10 群についても検討したが, 鎖 骨下静脈溝における鎖骨下静脈の位置 - 血管径や鎖
骨下静脈溝より外側 $10 \mathrm{~mm}$ および $20 \mathrm{~mm}$ での鎖骨 下静脈の位置, いずれも有意差はみとめられなかっ た。したがって, 頸部郭清術の郭清範囲は, 鎖骨下 静脈の位置や血管径の変化に影響を及ぼす可能性が 低いと考えられる。

以上の結果から, 頸部郭清術の前後において, 鎖 骨下静脈の位置や血管径の測定值の変化は少なく, 統計学的な有意差もみとめられなかった。放射線治 療については, 術後照射が 10 例中 7 例に施行され ていたが，鎖骨下静脈が照射野に含まれていた症例 は 2 例のみ（症例 4, 6) であった。このため, 放 射線治療による影響は，検討項目には入れなかっ た。 
表 3 鎖骨下静脈溝の矢状断面における鎖骨下静脈の血管径と 断面積の変化

\begin{tabular}{ccc|rrr}
\hline & \multicolumn{2}{c}{ 長径 $\times$ 短径 $(\mathrm{mm})$} & \multicolumn{3}{c}{ 断面積 $\left(\mathrm{mm}^{2}\right)$} \\
& 術前 & 術後 & 術前 & 術後 & 変化 \\
\hline 症例 1 & $15.8 \times 8.6$ & $13.9 \times 7.3$ & 106.7 & 79.7 & 27.0 \\
症例 2 & $12.8 \times 8.9$ & $12.9 \times 9.9$ & 89.4 & 79.4 & 10.0 \\
症例 3 & $13.8 \times 9.4$ & $12.2 \times 8.7$ & 101.8 & 83.3 & 18.5 \\
症例 4 & $13.8 \times 8.4$ & $12.5 \times 7.4$ & 91.0 & 72.6 & 18.4 \\
症例 5 & $11.2 \times 9.9$ & $12.5 \times 10.1$ & 87.0 & 99.1 & 12.1 \\
症例 6 & $12.9 \times 10.0$ & $11.2 \times 9.5$ & 101.3 & 83.5 & 17.8 \\
症例 7 & $12.4 \times 9.6$ & $12.2 \times 8.6$ & 93.4 & 82.4 & 11.0 \\
症例 8 & $12.5 \times 6.9$ & $12.1 \times 6.9$ & 67.7 & 65.5 & 2.2 \\
症例 9 & $13.2 \times 8.7$ & $12.9 \times 9.9$ & 90.1 & 100.3 & 10.2 \\
症例 10 & $13.9 \times 12.2$ & $14.2 \times 12.1$ & 133.1 & 134.9 & 1.8 \\
\hline 平均值 & $13.2 \times 9.3$ & $12.7 \times 9.0$ & 96.2 & 88.1 & 12.9 \\
\hline
\end{tabular}

表 4 鎖骨下静脈溝より $10 \mathrm{~mm}$ および $20 \mathrm{~mm}$ 外側での鎖骨下静脈の位置変化

\begin{tabular}{|c|c|c|c|c|c|c|}
\hline & 術前（mm） & $\begin{array}{l}\text { 外側 10mm } \\
\text { 術後 (mm) }\end{array}$ & 変化（mm） & 術前（mm） & $\begin{array}{l}\text { 外側 } 20 \mathrm{~mm} \\
\text { 術後 }(\mathrm{mm})\end{array}$ & 変化 (mm) \\
\hline 症例 1 & 30.71 & 31.63 & 0.92 & 26.99 & 29.42 & 2.43 \\
\hline 症例 2 & 31.92 & 29.64 & 2.28 & 27.85 & 26.35 & 1.50 \\
\hline 症例 3 & 34.85 & 32.21 & 2.64 & 29.56 & 23.49 & 6.07 \\
\hline 症例 4 & 27.20 & 25.43 & 1.77 & 24.00 & 24.53 & 0.53 \\
\hline 症例 5 & 29.71 & 30.42 & 0.71 & 27.73 & 27.53 & 0.20 \\
\hline 症例 6 & 32.33 & 30.73 & 1.60 & 28.92 & 28.64 & 0.28 \\
\hline 症例 7 & 29.35 & 31.85 & 2.50 & 27.28 & 28.35 & 1.07 \\
\hline 症例 8 & 33.38 & 35.20 & 1.82 & 28.85 & 26.59 & 2.26 \\
\hline 症例 9 & 29.49 & 29.21 & 0.28 & 26.35 & 26.28 & 0.07 \\
\hline 症例 10 & 28.66 & 26.85 & 1.81 & 29.49 & 30.49 & 1.00 \\
\hline 平均值 & 30.76 & 30.32 & 1.63 & 27.70 & 27.17 & 1.54 \\
\hline
\end{tabular}

\section{考察}

鎖骨下静脈は，鎖骨の下にあって第一肋骨の上を 通る静脈であり，前斜角筋の前を通る。かつ，『鎖 骨下静脈は第一肋骨と強く癒着しているため, この 部位に針を刺し，カテーテル挿入のためのラインを 確保するのがよい』と記されている1）。た，第一 肋骨には，前斜角筋停止部の隣で鎖骨下静脈が通る ところに，鎖骨下静脈溝と呼ばれる窪みがある2)。 すなわち，鎖骨下静脈は，鎖骨と第一胁骨の間で癒 着しており，かつ第一肋骨の鎖骨下静脈溝を通る, という特徴がある（図 1, 図 2)。

したがって，まずは，この部位における血管の 位置変化や血管径の変化, 血管の断面積を測定し た。さらに，鎖骨下静脈溝から外側 $10 \mathrm{~mm}$ および $20 \mathrm{~mm}$ における血管の位置変化を測定することによ
り，鎖骨下静脈全体での位置に偏位が生じるかどう かを検討した。

結果は，鎖骨下静脈溝が描出される部位において は, 鎖骨下静脈の位置変化, 血管径の変化, 断面積 の変化, いずれも数值の変化は少なく, 統計学的な 有意差もみとめられなかった。さらに, 鎖骨下静脈 溝より外側 $10 \mathrm{~mm}$ および $20 \mathrm{~mm}$ における血管の位 置変化についても同様であり, 数值の変化は少な く, 統計学的な有意差もみとめられなかった。

このことから, 頸部郭清術後においても, 鎖骨下 静脈からの中心静脈アプローチは可能であると考え られた。また，鎖骨下静脈への中心静脈カテーテル 留置は, 鎖骨と胸骨切痕を目安にした landmark 法 とエコーガイド下の穿刺法の 2 つの方法が主である が, 今回の結果からは, landmark 法でも可能であ ると考えられた。 
頭頸部がんの治療に際して, 経口摂取が困難な場 合であっても, 内視鏡下の胃瘦造設が普及し, 胃瘦 からの栄養や投薬が可能となってきた。しかしなが ら, 食道や胃に病変があり, 胃瘦が造設できない場 合がある。このような場合には中心静脈から栄養や 投薬を考慮せざるを得ない。中心静脈のルート確保 の経路としては, 内頸静脈, 鎖骨下静脈, 大腿静脈 が主なルートである。内頸静脈は手術操作が加わる ため, 鎖骨下静脈と大腿静脈との比較が中心になる が, 鎖骨下静脈からのルート確保は, 感染のリスク が少ないなどの利点がある ${ }^{3)}$ 。ただし，放射線照射 歴がある場合は, 感染のリスクとなるため, 他部位 からのアプローチを検討する必要があるものと思わ れる。

また, 中心静脈ポートが普及し, 在宅での栄養管 理や外来通院での化学療法が可能な施設も多い。こ のような患者に対して, 頸部郭清術後であっても, 鎖骨下静脈からの中心静脈確保が可能であれば，患 者の QOL が高まるのは言うまでもない。頸部郭清 術後の場合, 鎖骨下静脈からの中心静脈アプローチ は躊躇される場合があると思われるが，今回の検討
結果からは, 挿入経路として妥当であると考えられ た。

$$
\text { まとめ }
$$

今回の検討で, 頸部郭清術は鎖骨下静脈の位置に 大きな変化を与えないことが示唆された。解剖学的 にも，鎖骨下静脈は鎖骨下静脈溝を通り，第一肋骨 と強く固着している。頸部郭清術後においても, 鎖 骨下静脈からの中心静脈カテーテル留置は可能であ ると考えられた。

本論文の要旨は, 第 22 回日本頭頸部外科学会 $(2012$, 福島）にて発表した。

\section{文献}

1) Rohen JW, 横地千仍, Lutjen-Drecoll, E : 解剖学力 ラーアトラス第 6 版, 170-171, 医学書院, 東京, 2007.

2) Standring S, Ellis, H, Healy JC, et al: Gray's Anatomy, 952-959, Elsevier, Spain, 2005.

3) David C. McGee, Michael K. Gould: preventing complication of central venous catherization. N Engl J Med 348 : 1123-1133, 2003. 